\title{
CBFA2T2 Gene
}

National Cancer Institute

\section{Source}

National Cancer Institute. CBFA2T2 Gene. NCI Thesaurus. Code C104928.

This gene may be involved in tumor suppression. 